\title{
OPTIMIZATION OF PRODUCT INCORPORATING INDIAN BLACKBERRY (SYZYGIUM CUMINI) SEED FLOUR: A DIABETIC STUDY
}

\author{
Lakshmi E* \\ Department of Nutrition, S.R.M. College of Nursing, Potheri, Kattankulathur, Kancheepuram - 603203, Tamil Nadu, India. \\ Email: elakshmi20@gmail.com
}

Received: 24 October 2017, Revised and Accepted: 30 November 2017

\begin{abstract}
Objective: The objective of this study was to optimize recipes incorporating Indian blackberry (Syzygium cumini) seed flour (SCSF) in biscuits for its organoleptic feel and assess its impact on the anthropometric status of Type 2 diabetes mellitus.

Method: The study was designed to include 20 Type 2 and 20 normoglycemic controls. Biscuits were prepared using four blends (10 g, 15 g, 20 g, and $25 \mathrm{~g}$ ) of SCSF with a control. The diabetic subjects were supplemented with Indian blackberry SCSF (20 g) biscuits. Nutritional status was assessed such as body mass index (BMI) and waist-hip ratio (WHR). Results were analyzed statistically by two-way ANOVA and paired t-test.
\end{abstract}

Results: Statistically, there was a significant difference $(\mathrm{p}<0.001)$ in flavor and taste perception between diabetics and normoglycemic. The mean fasting and postprandial glucose level decreased much $(\mathrm{p}<0.001)$. There was a significant $(\mathrm{p}<0.001)$ decrease in the BMI and WHR.

Key words: Syzygium cumini, Optimization, Standardization, Body mass index, Waist-hip ratio.

(C) 2018 The Authors. Published by Innovare Academic Sciences Pvt Ltd. This is an open access article under the CC BY license (http://creativecommons. org/licenses/by/4. 0/) DOI: http://dx.doi.org/10.22159/ajpcr.2018.v11i3.23265

\section{INTRODUCTION}

Nature always stands as a gold mark to show the outstanding phenomena of symbiosis. There is an increasing interest in the natural product remedies for diabetes with a basic approach toward the nature. The World Health Organization has also substantiated the use of herbal remedies in the management of diabetes [1]. Taste disorder is a common observation in Type 1 and Type 2 diabetes due to neuropathy [2]. Syzygium cumini (family Myrtaceae) commonly known as jamun, black plum, and Indian blackberry is a tropical fruit tree native to India. The seeds have been reported to be rich in flavonoids, a well-known antioxidant, which accounts for the scavenging of free radicals and protective effect on antioxidant enzymes [3]. The ethanolic extract of $S$. cumini seeds decreased blood sugar level in alloxan-induced diabetic rats. Several studies using modern techniques have authenticated its use in diabetes and shown promising results [4]. It is difficult to continue the intake of these herbal plants for longer duration due to non-acquaintance of consumption form and nonacceptability of taste in their original form (powder form). Efforts are needed to develop food-based nutritional supplements using these herbal plant seeds which can serve as an alternate, as they are economical and socioculturally viable and acceptable [5]. Bakery products are considered as a ready-to-eat, convenient, and inexpensive means of taking food in hygienic way. Incorporating S. cumini seed flour (SCSF) in biscuits is a novel approach toward preparing new product for diabetes. Sensory analysis of a product is related to the organoleptic feel of the product. They are the visible attributes such as appearance and color, the tactile feel consists of texture and the olfactory and gustatory sensation are the flavor per se and taste per se [6]. Based on this information, the current paper focused on optimizing recipes incorporating Indian blackberry SCSF in biscuits for its organoleptic evaluation and assess the impact on the anthropometric status and the blood profile of Type 2 diabetes

\section{METHOD}

The study was approved by the research committee of Sri Avinashilingam Deemed University and designed to include eligible Type 2 diabetics. The ingredients for recipe standardization were procured from Chintamani supermarket (Coimbatore)

\section{Sample size}

Purposive method of sampling procedure was followed. 20 Type 2 diabetes mellitus and 20 normoglycemic controls were selected from among the staff members. Eligibility criteria included women in the age of at least 35-45 years, willing to take part in the study. A written consent was obtained and was appraised of the study.

Optimization and organoleptic evaluation of recipe

The recipes were standardized in the food science (bakery - conventional firewood oven) laboratory for their repeated consistency and packed in airtight container. The recipe had four variations with four blends $(10 \mathrm{~g}$, $15 \mathrm{~g}, 20 \mathrm{~g}$, and $25 \mathrm{~g}$ ) of SCSF incorporation with a control (Table 1).

Scorecards were developed using product-related lexicon based on 5 -point hedonic scale rating. The recipes were coded as $\mathrm{S}_{1}, \mathrm{~S}_{2}, \mathrm{~S}_{3}$, and $\mathrm{S}_{4}$ to prevent any bias. The panel members were invited by $12.30 \mathrm{pm}$ for sensory analysis. A glass of water was provided to rinse their mouth each time they tasted a different variation (Table 2).

\section{Intervention}

The diabetic subjects were supplemented with Indian blackberry SCSF (20 g) biscuits (SCSF) for 20 days at the rate of 5 biscuits per day. The biscuits were distributed on weekly basis to make sure regular consumption ( 2 biscuits before breakfast and 3 biscuits before lunch) as per instructions.

\section{Assessment}

The Nutritional effect of Indian blackberry SCSF (20 g) biscuits (SCSF) was evaluated by anthropometric parameters such as body mass index (BMI) and waist-hip ratio (WHR).

\section{Statistical analysis}

The recipe optimization was evaluated by two-way ANOVA with interaction and post hoc test for paired comparison. Paired t-test analysis was used to assess if significant differences existed in anthropometric parameters of the subjects at the end of self-control period. 


\section{RESULTS}

Acceptability of food products in terms of sensory variables is an important step in determining research priority [7]. Statistically, there was a significant difference $(\mathrm{p}<0.001)$ on evaluation of biscuits at all four levels of SCSF incorporation between diabetics and normoglycemic (Fig. 1).

Bitter taste and astringent flavor was sensed by diabetic subjects only at $25 \%$ level of SCSF incorporation. Whereas the normoglycemic subjects sensed at lower concentration (10\%). Pathological changes in the peripheral nerves of diabetics affect the myelin sheath resulting in reduced threshold for bitter taste [8]. The results showed a significant $(p<0.001)$ difference of flavor interaction between patients and attributes at all four levels (Table 3).

The post hoc Tukey test revealed a significant difference $(\mathrm{p}<0.005)$ in flavor and taste perception between the experimental and control group. The diabetic mean was higher $(3.7 \pm 0.10)$ compared to normal subjects $(2.8 \pm 0.11)$ at $15 \%$. The diabetics have lesser acuity for bitter taste and flavor [9]. A significant difference $(\mathrm{p}<0.005)$ in taste perception was also observed by post hoc Tukey test at each of the four levels of fortification. The mean score was higher $(4.8 \pm 0.09)$ in the experimental group compared to control $(3.55 \pm 0.11)$ group at $10 \%$. Continuously, a higher mean score was rated by diabetics compared to normoglycemic. There was a significant $(\mathrm{t}=8.36, \mathrm{p}<0.0001)$ decrease in the BMI at the posttest $\left(20^{\text {th }}\right.$ day) stage to $24.84 \pm 1.139$ with

Table 1: Ingredients in biscuits preparation

\begin{tabular}{ll}
\hline Ingredients & Amount \\
\hline Whole wheat flour (g) & 250 \\
Refined oil (ml) & 75 \\
Sugar free (powder) (g) & $3-5$ \\
SCSF (hypoglycemic seed flour) (g) & 50 \\
Ammonia powder (g) & $4-5$ \\
Milk & 75 \\
Salt & to taste \\
\hline
\end{tabular}

$250 \mathrm{~g}=50 \mathrm{~g}$ SCSF. $100 \mathrm{~g}=20 \mathrm{~g}$ SCSF, $250 \mathrm{~g}=12$ biscuits $100 \mathrm{~g}=5$ biscuits,

SCAF: Syzygium cumini seed flour

Table 2: Scorecard to evaluate quality of biscuits

\begin{tabular}{|c|c|c|c|c|c|}
\hline Appearance & Color & Texture & Flavor & Taste & Score \\
\hline Very good & Cream & Crisp & Biscuit flavor & Good & 5 \\
\hline Good & $\begin{array}{l}\text { Creamy } \\
\text { yellow }\end{array}$ & $\begin{array}{l}\text { Slightly } \\
\text { crisp }\end{array}$ & $\begin{array}{l}\text { Mild } \\
\text { blackberry } \\
\text { flavor }\end{array}$ & Fair & 4 \\
\hline Fair & $\begin{array}{l}\text { Light } \\
\text { yellow }\end{array}$ & Soft & $\begin{array}{l}\text { Strong } \\
\text { blackberry } \\
\text { flavor }\end{array}$ & $\begin{array}{l}\text { Astringent } \\
\text { taste }\end{array}$ & 3 \\
\hline Poor & Brown & $\begin{array}{l}\text { Fairly } \\
\text { hard }\end{array}$ & $\begin{array}{l}\text { Astringent } \\
\text { flavor }\end{array}$ & $\begin{array}{l}\text { Slightly } \\
\text { bitter }\end{array}$ & 2 \\
\hline Very poor & $\begin{array}{l}\text { Dark } \\
\text { brown }\end{array}$ & Very hard & $\begin{array}{l}\text { Unacceptable } \\
\text { flavor }\end{array}$ & Bitter & 1 \\
\hline
\end{tabular}

intervention of SCSF biscuits. BMI is an excellent indicator of the weight status of a person. Indians are unique and at risk of Type 2 diabetes at a lower BMI [10]. More than the weight, it is the shape of the body that determines the risk for many diseases. Lupeol, a phytoconstituent in $S$. cumini seeds, is known to reduce the intestinal absorption of dietary carbohydrate and seems to increase serum insulin level [11]. The WHR gradually decreased from $1.05 \pm 0.09$ at the pretest to $0.87 \pm 0.1$ with SCSF biscuits intervention. WHR used along with BMI is a better indicator in predicting risk for many of the serious disorders such as diabetes and high blood pressure [12]. The phytoconstituents such as Vitamin C, gallic acid, and tannins help to improve $\beta$-cell function [13]. There was a significant difference $(\mathrm{p}<0.05)$ in the BMI and WHR in diabetics before and after supplementation (Table 4).

Bioavailability of these bioactive components is dependent on food preparation processes, gastrointestinal digestion, absorption, and metabolism [14].

\section{DISCUSSION}

The pathogenesis of diabetes and its management by oral hypoglycemic agents has stimulated great interest in recent years. Despite much progress in the management of diabetes mellitus by synthetic drugs, the search for indigenous natural antidiabetic agents is still going on. The study revealed a lower sensitivity to bitter flavor and taste modality in diabetics. The threshold for bitter taste was perceived only at higher concentration of $25 \%$ by diabetics in biscuits. Similar studies on sensory analysis treatment of $81 \%$ maida, $9 \%$ jamun seed powder, and $10 \%$ finger millet flour secured maximum score for color, taste, flavor, and acceptability [15]. Indian blackberry SCSF (20 g) is thought to affect anthropometric status by affecting the BMI and WHR. Similar studies on the hypoglycemic activity of ethanol extract of $S$. cumini seed kernel at a concentration of $100 \mathrm{mg} / \mathrm{kg}$ of body weight significantly decreased the levels of blood glucose, in normal and non-insulin dependent diabetes mellitus rats, and whole seeds showed a moderate hypoglycemic effect [16]. Whereas, our study shows a decrease in the BMI and WHR. Several mechanisms to account for these effects are proposed. One of the most well-known properties of the polyphenols, especially flavonoids, phenolic acids, and tannins, on carbohydrate metabolism is inhibition of $\alpha$-glucosidase and $\alpha$-amylase, the key enzymes responsible for the digestion of dietary carbohydrates to glucose and body weight [17]. It

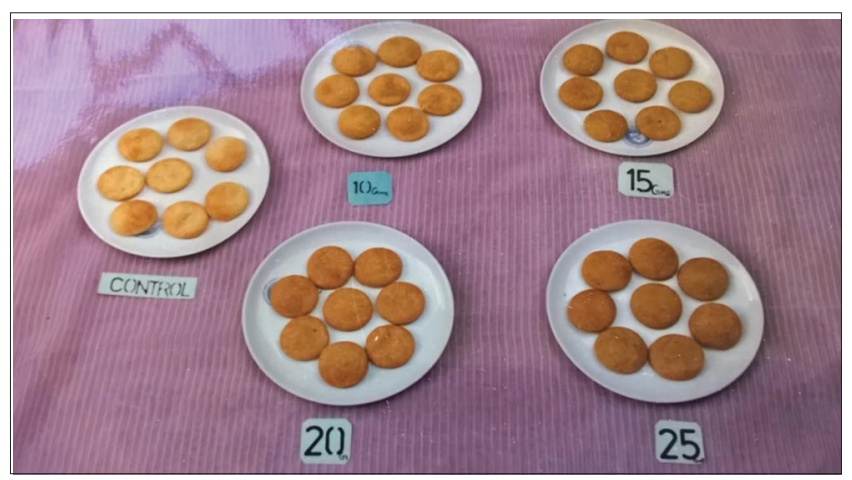

Fig. 1: Biscuits of variations with (Syzygium cumini) seed flour

Table 3: Organoleptic evaluation of biscuits as rated by diabetics and normoglycemic

\begin{tabular}{|c|c|c|c|c|c|c|c|c|c|c|c|}
\hline \multirow[t]{2}{*}{ Variable } & \multicolumn{4}{|l|}{ Diabetic } & \multicolumn{4}{|c|}{ Normoglycemic } & \multicolumn{3}{|l|}{$\mathbf{p}$} \\
\hline & $10 \mathrm{~g}$ & $15 \mathrm{~g}$ & $20 \mathrm{~g}$ & $25 \mathrm{~g}$ & $10 \mathrm{~g}$ & $15 \mathrm{~g}$ & $20 \mathrm{~g}$ & $25 \mathrm{~g}$ & Patients & Variation & $\mathbf{P} \times \mathrm{V}_{1}$ \\
\hline Appearance & $5 \pm 0^{\mathrm{a}}$ & $3.15 \pm 0.10^{c}$ & $4.2 \pm 0.09^{b}$ & $4.8 \pm 0.09^{a}$ & $4.05 \pm 0.05^{b}$ & $4.7 \pm 0.16^{\mathrm{a}}$ & $4 \pm 0^{\mathrm{b}}$ & $5 \pm 0^{\mathrm{a}}$ & 0.014 & $<0.001$ & $<0.001$ \\
\hline Color & $4.75 \pm 0.09^{a}$ & $4 \pm 0.10^{\mathrm{ac}}$ & $4 \pm 0.21^{\mathrm{ac}}$ & $3.25 \pm 0.20^{\mathrm{cd}}$ & $4.15 \pm 0.08^{\mathrm{ab}}$ & $3.65 \pm 0.18^{b c}$ & $2.75 \pm 0.23^{d}$ & $3.3 \pm 0.17^{\mathrm{cd}}$ & $<0.001$ & $<0.001$ & 0.002 \\
\hline Texture & $4.95 \pm 0.05^{\mathrm{a}}$ & $4.05 \pm 0.05^{b c}$ & $3.85 \pm 0.10^{\mathrm{bc}}$ & $2.8 \pm 0.09^{d}$ & $4.75 \pm 0.09^{\mathrm{a}}$ & $4.2 \pm 0.09^{\mathrm{b}}$ & $3.75 \pm 0.12^{c}$ & $2.85 \pm 0.08^{\mathrm{d}}$ & 0.697 & $<0.001$ & 0.224 \\
\hline Flavor & $4.8 \pm 0.09^{\mathrm{a}}$ & $3.7 \pm 0.10^{c}$ & $2.85 \pm 0.08^{d}$ & $3.6 \pm 0.11^{c}$ & $4.2 \pm 0.09^{\mathrm{b}}$ & $2.8 \pm 0.11^{\mathrm{d}}$ & $1.5 \pm 0.11^{\mathrm{e}}$ & $1.5 \pm 0.11^{\mathrm{e}}$ & $<0.001$ & $<0.001$ & $<0.001$ \\
\hline Taste & $4.8 \pm 0.09^{\mathrm{a}}$ & $4.3 \pm 0.10^{\mathrm{b}}$ & $3.7 \pm 0.10^{c}$ & $3.2 \pm 0.09^{d}$ & $3.55 \pm 0.11^{\mathrm{cd}}$ & $3.3 \pm 0.10^{\mathrm{cd}}$ & $2.2 \pm 0.09^{\mathrm{e}}$ & $1.45 \pm 0.11^{\mathrm{f}}$ & $<0.001$ & $<0.001$ & 0.003 \\
\hline
\end{tabular}

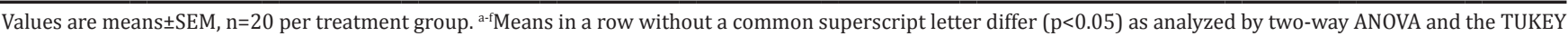
test. ${ }^{1} \mathrm{P} \times \mathrm{V}=$ Patients $\times$ Variation interaction effect. SEM: Standard error of the mean 
Table 4: Anthropometric measurements of the diabetic subjects

\begin{tabular}{|c|c|c|c|c|}
\hline \multirow{2}{*}{$\begin{array}{l}\text { Anthropometric } \\
\text { indices }\end{array}$} & \multirow{2}{*}{$\frac{\text { Pretest }}{0^{\text {th }} \text { day }}$} & \multicolumn{2}{|l|}{ Posttest } & \multirow[t]{2}{*}{$\mathrm{t}$ value } \\
\hline & & $10^{\text {th }}$ day & $20^{\text {th }}$ day & \\
\hline BMI & $26.65 \pm 0.92$ & $25.6 \pm 1.15$ & $24.84 \pm 1.13$ & $8.36, p<0.0001$ \\
\hline WHR & $1.05 \pm 0.09$ & $0.98 \pm 0.11$ & $0.87 \pm 0.1$ & $8.01, p<0.0001$ \\
\hline
\end{tabular}

Significance $=p<0.05$. BMI: Body mass index, WHR: Waist-to-hip ratio

contains several phytoconstituents belonging to the class of alkaloids, glycosides, flavonoids, and volatile oil.

\section{CONCLUSION}

The study substantiates a lower sensitivity to bitter flavor and taste modality in Type 2 diabetics and the nutritional effect of Indian blackberry SCSF (20 g) biscuits (SCSF) in reducing the BMI and WHR among Type 2 diabetes. Its proven medicinal properties make it a wholesome ingredient for regular consumption. It is suggested that diabetic subjects be encouraged to use these herbal plant products in their daily food as they are economically viable and socioculturally acceptable.

\section{AUTHORS' CONTRIBUTIONS}

E. Lakshmi: Substantial contributions to conception and design analysis, interpretation of data and drafting the article and revising it critically for important intellectual content and, final approval of the manuscript version to be published.

\section{CONFLICTS OF INTERESTS}

Conflict of interest declared none.

\section{REFERENCES}

1. Brahmachari HD, Augusti KT. Hypoglycaemic agents from Indian indigenous plants. J Pharm Pharm 1961;13:381-2.

2. Hardy SL, Brennand CP, Wyse BW. Taste thresholds of individuals with diabetes mellitus and of control subjects. J Am Diet Assoc
1981;79:286-9.

3. Ravi K, Sivagnanam K, Subramanian S. Anti-diabetic activity of Eugenia jambolana seed kernels on streptozotocin-induced diabetic rats. J Med Food 2004;7:187-91.

4. Farswan M, Mazumder PM, Parcha V, Upaganlawar A. Modulatory effect of Syzygium cumini seeds and its isolated compound on biochemical parameters in diabetic rats. Pharmacogn Mag 2009;5:127-33.

5. Gaphor MS, Raz AS. The evaluation of taste threshold for four main tastes between diabetic and healthy individuals. Eur Sci J 2014;10:435-9.

6. Costell E, Tárrega A, Bayarri S. Food acceptance: The role of consumer perception and attitudes. Chem Percept 2010;3:42-50.

7. Seidemann J, Paul PC, Palmer HH. Herausgeber. Food Theory and Applications. New York, London, Sydney, Toronto: John Wiley \& Sons, Inc.; 1972

8. Gondivkar SM, Indurkar A, Degwekar S, Bhowate R. Evaluation of gustatory function in patients with diabetes mellitus Type 2. Oral Surg Oral Med Oral Pathol Oral Radiol Endod 2009;108:876-80.

9. Olson RK. Taste changes in diabetes mellitus. Nutr Rev 1982;40:236-7.

10. World Health Organization. World Health Organization: Waist Circumference and Waist-Hip Ratio: Report of a WHO Expert Consultation. Geneva: World Health Organization; 2008-2011.

11. D'Mello PM, Jadhav MA, Jolly CI. Free radical scavenging activity of Syzygium cumini and ficus bengalensis-Plants used in Ayurveda for diabetes mellitus. Indian Drugs 2000;37:518-20.

12. Ashish P, Varsha T. Study of BMI and waist hip ratio of Indians with Type-2 diabetes mellitus. Int J Med Res Rev 2014;2:592-8.

13. Arshiya S, Hefazat HS, Tarique M, Paramdeep B, Ranjan kumar. A comprehensive study on literature evidence, clinical studies and practices of herbal drugs for diabetic neuropathy and cardiomyopathy. Asian J Pharm Clin Res 2017;10:30-7.

14. Sankaran M, Velusamy V, Amla MK. A novel ayurvedic herb as a functional food for health benefits-A mini review. Int J Pharm Pharm Sci 2013;5:1-4.

15. Kalse SB, Swami SB, Sawant AA, Thakor NJ. Development and quality evaluation of Jamun seed powder fortified biscuit using finger millet. J Food Process Technol 2016;7:1-3.

16. Chandavarkar S, Mamle Desai SN. Diuretic activity of different extracts of bark of Syzygium cumini (linn.) skeels. Int J Res Ayurveda Pharm 2014;5:102-4

17. Sharma S, Mehta BK, Mehta D, Nagar H, Mishra A. A review on the pharmacological activity of Syzygium cumini extracts using different solvent and their effective doses. Int Res J Pharm 2012;3:54-6. 